Dokuz Eylül Üniversitesi-Mühendislik Fakültesi Fen ve Mühendislik Dergisi

Cilt 20, Sayı 59, Mayıs, 2018
Dokuz Eylul University-Faculty of Engineering Journal of Science and Engineering Volume 20, Issue 59, May, 2018

DOI: $10.21205 /$ deufmd. 2018205932

\title{
Sayısal Görüntü İşleme ile Titreşim Yer Değiştirmelerinin ölçümü ve Modal Parametre Tayini
}

\author{
Yıldırım Serhat Erdoğan ${ }^{* 1}$ \\ ${ }^{1}$ Yıldız Üniversitesi, İnşaat Mühendisliği Fakültesi,İnşaat Mühendisliği Bölümü, \\ 34220, İstanbul (ORCID:0000-0001-9206-5474)
}

(Alınış / Received: 10.03.2017, Kabul / Accepted: 20.03.2018, Online Yayınlanma / Published Online: 15.05.2018)

\begin{abstract}
Anahtar Kelimeler Sayısal görüntü işleme, Operasyonel Modal Analiz, Görüntü tabanlı şablon eșletirme, Kanade-LucasTomasi algoritmasi, Görsel akıs algoritması

Özet: İnşaat mühendisliği yapılarında deneysel yöntemler ile elde edilen yer değiștirme gibi fiziksel büyüklükler ile modal parametreler yapının mevcut durumu hakkında önemli bilgiler içermektedir. Bu parametrelerin tayini genellikle ivme, hız ve yer değiştirme ölçerler ile toplanan verilerin zaman veya frekans alanında analizi ile yapılmaktadır. Fakat bu verilerin alışılagelmiş yöntemler ile elde edilmesi çoğu kez pratik olmamaktadır. Son yıllarda ise sayısal görüntü ișleme teknikleri titreșim verilerinin çok daha ucuz ve kolay bir şekilde toplanmasına olanak tanımaktadır. Bu çalışmada, sayısal görüntü işleme teknikleri ile yapı titreşimlerinin ölçülmesi ve deneysel modal parametrelerin (doğal frekans, mod şekilleri v.b.) tayini üzerinde durulmuştur. Alüminyum alaşımdan inşa edilmiş dört katlı tek açıklıklı model bir yapı üzerinde üç yöntem test edilmiştir. Bu yöntemler sırasıyla Kanade-Lucas-Tomasi (KLT) algoritması, korelasyon tabanlı şablon eșleștirme ve görsel akış yöntemleridir. İlk iki yaklașımda, titreşim kaynaklı yer değiştirmeler ölçülürken diğer yaklaşımda hız büyüklükleri ölçülebilmektedir. Ayrıca tüm yöntemlerde doğal hedeflerin takibi ile bu büyüklükler bulunabilmektedir. Bu çalışma kapsamında belirtilen yöntemlerin performansları, test yapısından ivmeölçerler ve LVDT yardımıyla toplanan veriler ile karşılaştırma yapılarak değerlendirilmiştir.
\end{abstract}

\section{Computer Vision Based Vibrational Displacement Measurement and Modal Identification}

\begin{tabular}{|c|c|}
\hline $\begin{array}{l}\text { Keywords } \\
\text { Computer vision } \\
\text { processing, } \\
\text { Operational } \\
\text { modal analysis, } \\
\text { Vision based } \\
\text { template } \\
\text { matching, } \\
\text { Kanade-Lucas- } \\
\text { Tomasi algorithm, }\end{array}$ & $\begin{array}{l}\text { Abstract: Physical parameters such as displacements and modal } \\
\text { parameters that are obtained from experimental tests contain } \\
\text { crucial information about the current state of civil engineering } \\
\text { structures. Identification of those parameters has been usually } \\
\text { carried out by the time and the frequency domain analysis of the } \\
\text { data obtained by means of accelerometers, velocity and } \\
\text { displacement transducers. However, it is not always practical to } \\
\text { obtain such experimental quantities via conventional methods. } \\
\text { Recently, digital image processing techniques have made it }\end{array}$ \\
\hline
\end{tabular}


Optical Flow Algorithm

possible to measure vibrational data in a way that is much cheaper and easier. In this study, computer vision based measurement of structural vibrations and identification of experimental modal parameters (natural frequency, mode shapes etc.) are emphasized. Three popular methods are introduced and tested on a 4-storey single-span laboratory structure, which is made of aluminum alloy. The investigated methods are KanadeLucas-Tomasi (KLT) algorithm, a correlation-based template matching method and an optical flow method, respectively. While the first two methods are used to measure the vibrational displacements, the last approach is suitable for velocity field measurements. In addition, all methods are capable of capturing vibrational quantities by tracking natural targets located on the structure. In this study, the presented methods are discussed and their performances are evaluated by comparing the results with conventional accelerometers and LVDT measurements.

*Sorumlu yazar: serhate@yildiz.edu.tr, yserdogan@itu.edu.tr

\section{Giriş}

İnşaat mühendisliği yapılarının modal tanılaması son birkaç on yıldır oldukça popüler olmuştur. Modal tanılama, zorlanmış veya çevre titreșimleri altında yapıdan ölçülen ivme, hız ve yer değiștirme gibi büyüklüklerin analizi ile doğal frekans, mod şekli, sönüm oranı gibi büyüklüklerin belirlenmesini kapsamaktadır. Bu büyüklükler yapının dinamik karakteristikleri ile doğrudan ilişkili olduğundan değişimleri yapının dinamik davranışını önemli ölçüde etkilemektedir. Bundan dolayı yapılarda hasar durumunun belirlenmesinde önemli rol oynamaktadırlar.

Deneysel modal parametrelerin belirlenmesi genelde piezoelektrik (PZT) veya micro elektromekanik (MEMS) ivmeölçerler ile çevre titreşimlerinden elde edilen ivme kayıtlarının analizi ile yapılmaktadır. Bunların yanında hız ve yer değiştirmelerin ölçülmesinde kullanılan çok sayıda farklı sensor tipleri de mevcuttur [1]. İvme kayıtlarının analizi genellikle Frekans Alanı Ayrıklaştırma [2] veya Stokastik Altuzay Tanılama [3] gibi yöntemler ile frekans ve zaman alanında yapılmaktadır [4]. Sonraki așamada, elde edilen bu veriler yapisal hasar ve mevcut durum belirlemesi, deprem güvenliği tahmini gibi yapı sağlığı izleme (YSİ) alanlarında kullanılmaktadır [5].

Son yıllarda modal tanılama ve YSİ alanlarında kullanılacak verilerin toplanması için çok daha yenilikçi bir yol olan sayısal görüntü işleme yöntemleri ön plana çıkmıştır. $\mathrm{Bu}$ yöntemlerde, yapıların hareketi bir kamera yardımıyla çekilen görüntülerin işlenmesi ile tespit edilebilmektedir. Alışılagelmiş yöntemlerde sensörlerin yapıya yerleştirilmesi, kablolama gibi zaman ve işçilik gerektiren uygulamaların yanı sıra sensör ve veri toplama cihazlarının yüksek maliyeti gibi dezavantajlar bulunmaktadır. Sayısal görüntü işlemede ise ortalama bir dijital kamera, bilgisayar ve gerekli yazılımlar ile daha pratik bir şekilde titreşim ait büyüklükler ölçülebilmektedir. İșlemler esnasında yapıya herhangi bir müdahaleye gerek kalmamakta ve tamamen uzaktan ölçüm yapılabilmektedir.

Görüntü tabanlı yer değiştirme ölçümü ve modal tanılamayla ilgili çalışmalar son yıllarda oldukça hız kazanmıştır. Bu çalışmalarında bazılarında yapıya yerleştirilmiş belirli özelliklere sahip yapay hedeflerin takibi ile yer 
değiştirmeler ölçülürken, doğal hedeflerin takibiyle yer değiștirme ölçümü son yıllarda daha fazla ilgi görmektedir [6-8]. Bu șekilde yöntem daha pratik bir şekilde uygulanmaktadır. [9-11] gibi çalışmalarda görüntü tabanlı hareket yakalama algoritmaları laboratuvar ortamında test yapılarına uygulamışlardır. Bu yöntemlerin köprü tipi gerçek yapıların modal parametrelerinin tayinindeki kullanımı ise $[12,13]$ 'de bulunabilir. Asma köprülerde askı kablolarındaki kuvvetlerin görüntü tabanlı hareket yakalama ile tespitiyle ilgili özgün bir çalışma [14]'de sunulmuştur. [15] ise görüntü yakalamada kullanılan çeşitli algoritmalar ve uygulamaları hakkında geniş bir literatür taraması sunmuştur.

$\mathrm{Bu}$ çalışmada, pratik uygulamalardaki kullanımı açısından yüksek potansiyele sahip Kanade-Lucas-Tomasi (KLT) algoritması [16], resimlerin korelasyonunu temel alan bir şablon eşleștirme yöntemi [17] ile resimlerdeki yoğunluk değişiminden yararlanarak hız alanının belirlenmesinde kullanılan görsel akış tekniğinin [18] performansları ele alınmıștır. Bu algoritmalar yapısal sağlık izleme çalışmaları kapsamında inşaat mühendisliği yapılarının dış yükler altında yer değiştirmelerinin ölçülmesinde sıkça kullanılmaktadır. [10]'da KLT algoritması, altı katlı bir laboratuvar yapısının yapısal tanılaması için gerekli titreşimlerin ölçülmesinde kullanılmıştır. Ayrıca KLT algoritması kullanılarak bir futbol stadyumunun tribünlerindeki yer değiștirmeler ölçülmüştür [7]. Korelasyon tabanlı şablon eşleştirme yöntemi ise pratikliği nedeniyle uygulamada sıkça kullanılmıştır. [12]'de şablon eşleștirme ile laboratuvar ortamında basit bir kiriş ile Manhattan Köprüsü'nün titreşim yer değiştirmeleri başarılı bir şekilde ölçülmüştür. Yöntem asma bir köprünün askı kablolarının titreşim frekanslarının bulunmasında kullanılmakla beraber [14] bir demiryolu köprüsünün tren geçişleri esnasındaki titreşimlerinin ölçülmesinde de kullanılmıştır [6]. Görsel akış algoritması ise asma köprü kablolarının titreşim ölçümlerinde sabit bir referans hedefe ihtiyaç olmaksızın uygulanmıștır [20].

Mevcut çalışma, bahsi geçen üç algoritmanın teorik altyapısını sunmakta ve laboratuvar ortamında oluşturulmuş bir test yapısı üzerinde karşılaştırılmalı olarak değerlendirmektedir. Algoritmalar, yapay ve yapı üzerindeki doğal hedeflerin takibi ile yer değiştirme ölçümünde kullanılmıştır. Tüm yöntemler ivmeölçer ve LVDT elde edilen ivme ve yer değiştirme kayıtları ile karşılaştırılmıştır.

\section{Sayısal Görüntü İşleme ile Yer Değiștirme Ölçümü}

\subsection{KLT algoritması}

KLT algoritması ile yer değiștirme ölçümü genel olarak dört adımdan oluşmaktadır. Bunlar; 1) referans video karesi içinde izlenecek olan alanın (İlgi Merkezi) belirlenmesi 2) bu alan içinde belirteç noktalarının tespiti 3) tespit edilen belirteç noktaların izlenmesi 4) varsa yanlış belirteç noktaların kaldırılmasıdır.

KLT algoritması video karesi içinde belirlenen bir ilgi merkezinin sonraki karedeki konumunu Denklem (1) ile belirler. Burada $I$ ve $J$, sirasiyla referans ve sonraki karelerin $\boldsymbol{x}=[x, y]$ noktasındaki piksel yoğunluğunu, $\boldsymbol{D}$ ve 1 , $2 \times 2$ deformasyon ve birim matrisini, $\boldsymbol{d}$ ise yer değiştirmeyi göstermektedir. Genellikle deformasyon matrisinin tahminindeki zorluk, yer değiştirmelerin tahmininde hataya neden olmaktadır. Bundan dolayı sadece ötelenmenin göz önüne alındığı modeller tercih edilmekte ve deformasyon matrisi sıfır olarak kabul edilmektedir. 
$f(A x+d)=I(x)$

$A=1+D$

İlgi alanının yer değiştirmesi $d=\left[x^{x} y^{\prime}\right]$ Denklem 3 'de verilen hata (uyuşmazlık) fonksiyonunun minimize edilmesiyle bulunmaktadır. Denklemdeki $W$, video karesinde belirlenen ilgi alanını, $w(x)$ ise piksel noktalarına vurgu yapan ağırlık fonksiyonuna karşı gelmektedir ve genel halde 1 alınabilir.

$E=\iint_{W}[/(A x+d)-I(x)]^{z_{w}}(x) d x$

Hata fonksiyonu minimum değeri için yer değiştirmeye göre bir kez türetilip sıfira eșitlenir. Ayrıca $/(A x+d)$ 'nin Denklem (4)'de verilen Taylor açlımı bu denklemde yerine konursa Denklem (5) elde edilir.

$f(A x+d)=j(x)+g^{T} d$

$\iint_{W} g\left(g^{T} d\right) w d x d y+\iint_{W}[(x)-I(x)] g$

Burada,

$\left.\left.g^{T}=\left[g_{x}, g_{y}\right]=[\partial] / \partial x, \partial\right] / \partial y\right]$ 'dir.

Denklem (5) 'in çözümünden yer değiștirmeler bulunabilir. Fakat bu denklem doğrusallaştırılmış olduğundan tam olarak sağlanmaz. Bunun için Newton-Raphson gibi iteratif yöntemler kullanılabilir. Daha önce belirtildiği gibi ilgi alanının deformasyonundan ziyade yer değiştirmesiyle ilgileniyorsa Denklem (5) yerine ilgi alanı içindeki bir belirteç noktasının yer değiștirmesi $\boldsymbol{d}$ 'yi veren daha kompakt form olan Denklem (6)-(8) kullanılır. Denklemlerin türetilmesi ile ilgili daha fazla bilgi [16]'da bulunabilir.
$\mathbf{Z d}=\mathbf{c}$

$Z=g g^{T}=\left[\begin{array}{cc}g_{x}^{2} & g_{x} g_{y} \\ g_{x} g_{y} & g_{y}^{2}\end{array}\right]$

$c=[I(x)-j(x)] g$

Bir resimdeki belirteç noktaları parlaklık, ıșık değișimi ile ilgi alanının dönmesi, ölçeğinin değișimi gibi nedenlerden etkilenmeyen noktalardır. Bu noktaların tespiti için birçok yöntem önerilmiş olmakla beraber bu çalışmada Denklem (9) 'da verilen kriter kullanılmıştır. Burada, $\lambda_{1}$ ve $\lambda_{2}, Z$ matrisinin özdeğerleri, $\AA$ ise kullanıcı tarafından belirlenen bir eşik değerdir.

$\min \left(\lambda_{1}, \lambda_{2}\right)>\lambda$

\section{2. Şablon eşleştirme yöntemi}

$\mathrm{Bu}$ yöntem, referans resimden (video karesi) seçilen bir şablonun sonraki karelerdeki konumunun tespitine dayanmaktadır. Yer değiștirme, seçilen şablonun referans resimdeki konumunun us Qhrakio resimlerdeki konumundan çıarılmasıyla elde edilir (Denklem (10)). Şekil (1)'de yöntem için bir gösterim verilmektedir. Referans resimden seçilen şablonun sonraki resimlerle eşleştirilmesinde birçok benzerlik kriteri kullanılmaktadır. Bu çalışmada Denklem (11)'de verilen normalize edilmiş çapraz korelasyon katsayısı kullanılmıștır. Normalize edilmiș korelesyon katsayısı ışık gibi çevresel değişimlerden etkilenmemekle beraber resimdeki dönme ve oransal değişimlere daha az duyarlıdır. Ayrıca basit bir eşleștirme kriteri olması tercih nedeni olmaktadır.

$d=l\left(x, y, t_{i}\right)-l\left(x, y, t_{0}\right)$ 


$$
R(x, y)=\frac{\sum_{y=0}^{h-1} \sum_{i=0}^{W-1}\left(T\left(x^{\prime}, y^{\prime}\right)-\bar{T}\right)\left(I\left(x+x^{\prime}, y+y^{\prime}\right)-\bar{l}(x, y)\right)}{\sqrt{\sum_{y=0}^{h-1}\left(T\left(x^{\prime}, y^{\prime}\right)-\bar{T}\right)^{2} \sum_{y=0}^{W-1}\left(I\left(x+x^{\prime}, y+y^{\prime}\right)-\bar{l}(x, y)\right)^{2}}}
$$

Burada, $T(x, y) \quad$ ve $I(x, y) ; \quad(x, y)$ konumunda şablon ve mevcut resimdeki piksel değerlerini, $\bar{T}$ ve $\bar{I}(x, y)$ ise şablondaki ve mevcut resimdeki piksellerin ortalama değerlerini göstermektedir. Şablondaki piksel sayısı ise wxh kadardır. Böylece, seçilen ilgi alanının boyutu $W x H$ piksel olmak üzere $R(x, y)$ fonksiyonu her resim için $W$ - $w-1 x$ $H$ - $h$-1 defa hesaplanmaktadır. Bu şekilde elde edilen korelasyon fonksiyonunun piksel koordinatlarıyla değişimini gösteren örnek bir grafik Şekil (2)'de verilmiştir. Maksimum korelasyon değerine karşı gelen piksel koordinatları resim içinde şablonunun eşleştiği konumu göstermektedir. $\mathrm{Bu}$ noktada hatırlatılması gereken şablonun herhangi bir dönme yapmadığı sadece öteleme yaptığıdır. Dönme yapması durumunda şablonun konumunun tespitinde hatalar meydana gelecektir. $\mathrm{Bu}$ durumda, şablonun dönmesini de dikkate alan daha ileri algoritmalar kullanılabilir [19].

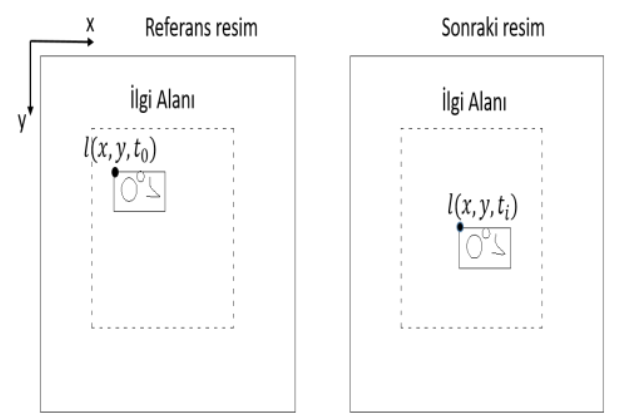

Şekil 1. Şablon eşleştirme

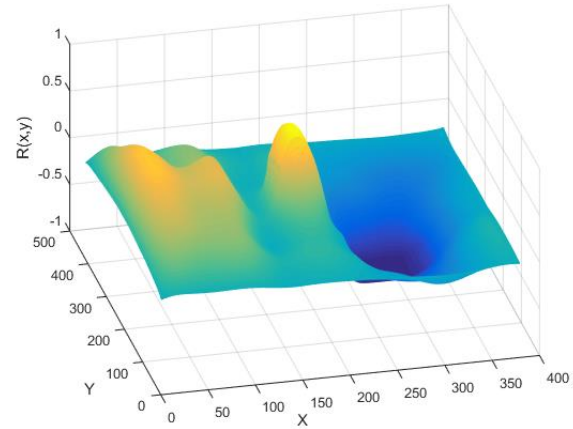

Sekil 2. Korelasyon fonksiyonunun piksel koordinatlarına göre değișimi

\subsection{Görsel akış algoritması}

Görsel akış tekniği, herhangi bir hedef noktaya gereksinim duymadan video kareleri arasındaki yoğunluk değişiminden yararlanarak hız alanının bulunmasında kullanılan etkili bir görüntü işleme yöntemidir. İki resim arasındaki görsel akışın bulunması Denklem (12)'nin çözülmesiyle mümkün olmaktadır.

$I_{x} \dot{x}+I_{y} \dot{y}=-I_{t}$

Burada $I_{x}, I_{y}$ ve $I_{t}$ sirasiyla piksel yoğunluklarının yatay ve düşey koordinatlar $x$ ve $y$ ile zaman adımı t 'nin kısmi türevleridir. Bu değerler sonlu farklar ile sayısal olarak hesaplanabilir. Değişkenler üzerindeki nokta zamana göre türevi göstermektedir. $\mathrm{Bu}$ denklemin çözümü resim üzerindeki tek bir noktadaki bilgi ile mümkün olmamaktadır. Yöntem kapsamında farklı yaklaşımlar ile Denklem (12)'nin çözümü için ek kısıtlar uygulanmaktadır. Bu çalışmada HornSchunck yöntemi benimsenmiştir. Bu yaklaşımda tüm resimdeki görsel akışın düzgün olduğu (noktadan noktaya ani değişimler yok) kabulü yapılmıștır. Buna 
göre yatay ve düşey hiz vektörleri $\dot{x} \dot{y}$, Denklem (13)'ün minimize edilmesiyle bulunmaktadır. Burada $\approx$ düzgünlük terimidir. Bu terim 1 olarak alınabilir. Resimler arasındaki hız farkı arttıkça daha yüksek değerler seçilebilir. Ayrıca Denklem (12)'nin çözümü için LucasKanade yöntemi de kullanılabilir.

$E=\int\left[\left(I_{x_{x}} \dot{x}+I_{y} \dot{y}+I_{t}\right)^{2} d x d y+c \iint\left(\frac{\partial \dot{x}}{\partial x}\right)^{2}+\left(\frac{\partial \dot{x}}{\partial y}\right)^{2}+\left(\frac{\partial \dot{y}}{\partial x}\right)^{2}+\left(\frac{\partial y}{\partial y}\right)^{2}\right\} d x d y$

Şekil (3)'de üç algoritmaya ait akış algoritmalara ait kodlar ve örnek bir diyagramları verilmiştir. Ayrıca videoya (21)'den ulaşılabilir.
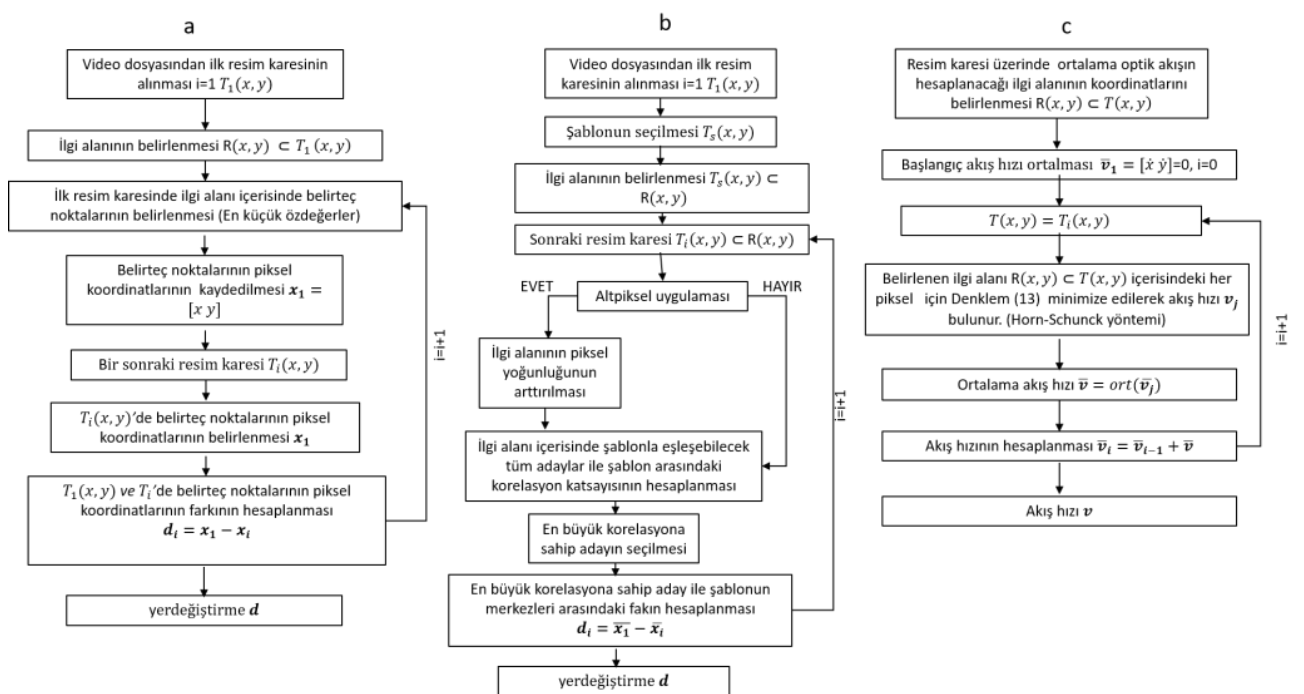

Şekil 3 Görüntü işleme yöntemlerine ait akış diyagramları a) KLT algoritması b)Şablon eşleștirme yöntemi c)Görsel akıș algoritması

\subsection{Altpiksel tahmini ile sonuçların iyileştirilmesi}

Yapı titreşimlerinin kaydedilmesinde kullanılan kameraya, lense, kameranın hedefe olan mesafesine veya titreşimin genliğine bağlı olarak resimdeki piksel yoğunluğu yer değiștirmelere oranla küçük olabilir. Bu durum kaydedilen yer değiștirmelerin hatalı olmasına neden olabilir. İdeal olarak, yer değiştirmelerdeki hatanın az olması için çekilen resimlerin geniş bir alanı kapsaması, seçilen șablonun büyük olması, piksel yoğunluğunun ve renk derinliğinin fazla olması istenir. Fakat bu durumda da kullanılacak ekipmanın maliyeti çok fazla olabilir. Piksel yoğunluğunun yer değiştirmelere oranla küçük olması durumunda, şablondaki piksel yoğunlukları çift doğrusal veya kübik interpolasyon ile arttırılabilir. Bunun için Matlab programlama dilinde 'imresize' fonksiyonu kullanılabilir. Şekil (4)'de çeşitli alt piksel ölçeklendirme faktörü $\mathbb{k}$ için normalize edilmiş korelasyon katsayısının piksel konumuna göre değișimi verilmiștir. En büyük korelasyon katsayısının $x$ koordinatı $k=1, k=5$ ve $k=10$ için sirasiyla 9 , $44 / 5=8.8$ ve $89 / 10=8.9$ 'dur. Görüldüğü üzere maksimum korelasyon katsayısının konumu $k=1, k=5$ ve $k=10$ için sırasıyla $1, \quad 0.2$ ve 0.1 piksel hassasiyetiyle değişmektedir. 
Anlaşılacağı üzere piksel yoğunluğu bir şekilde bulunabilir. arttırılarak yer değiștirmeler daha hassas
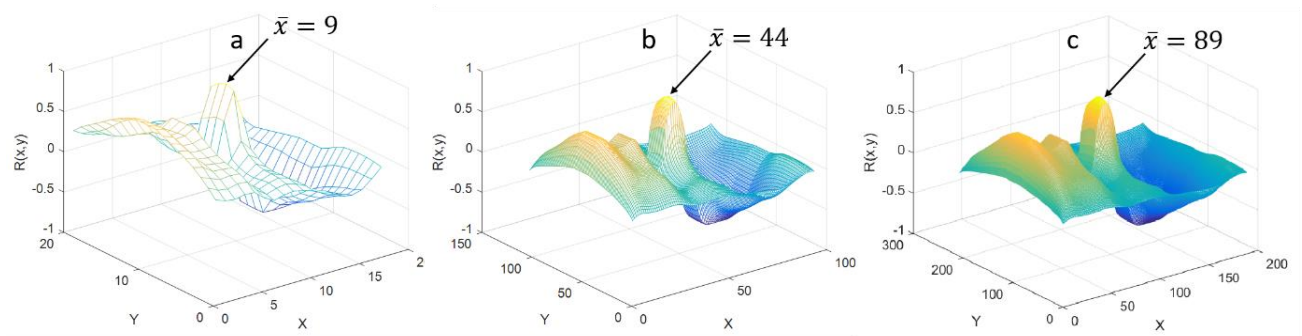

Şekil 4. Normalize edilmiş korelasyon katsayısı fonksiyonu a) $k=1$ (orijinal) b) $k=5$ c) $k=10$

\subsection{Kamera kalibrasyonu}

Resimlerde bir noktanın konumu piksel koordinatları ile tanımlanmaktadır. Başka bir değişle bir resimdeki iki noktanın arasındaki mesafe piksel koordinatları arasındaki fark ile ifade edilmektedir. Piksel sayısının mühendislik birim sistemindeki karşılığının bulunması için bir pikselin mühendislik sisteminde kaç birime $(\mathrm{m}$, $\mathrm{cm}, \mathrm{mm}$ ) karşı geldiğini bulmamız gerekir. Denklem (14) yardımıyla piksel cinsinden boyut $D_{\text {pikser }}$, mühendislik birimi cinsinden boyut d ye dönüştürülebilir. Burada $c\left(x_{m}\right)$ kameranın hedefe olan mesafesine bağlı bir katsayısıdır. $\mathrm{Bu}$ katsayısının belirlenmesi için, boyutları bilinen bir hedefin farklı mesafelerden çekilmiş fotoğrafları için her mesafede cisim boyutlarına karşı gelen piksel sayıları bulunur. Bu șekilde $e-x_{m}$ eğrisi elde edilir. $\mathrm{Bu}$ eğrinin denklemi en küçük kareler yöntemi ile kolayca bulunabilir. Bu şekilde ${ }^{c}$ katsayısı kameranın hedefe olan mesafesinin $\left(x_{m}\right)$ fonksiyonu olarak ifade edilebilir. Ayrıca ${ }^{c}$ katsayısı mesafe ile birlikte kamera lensinin optik ekseni ile hedef nesnenin yüzey normali arasındaki açının bir fonksiyonu olarak da ifade edilebilir. Çünkü gerçek uzaklık ile piksel uzaklığı arasındaki ilişki, bu açı ile de değișmektedir. Daha detaylı bilgi için [7] ile [12]'ye bakılabilir.

$$
d=c\left(x_{\mathrm{m}}\right) D_{\text {pilissel }}
$$

\section{Test Yapısı ve Düzeneği}

Algoritmaların değerlendirilmesinde kullanılan test yapısı, $0.30 \times 0.40 \mathrm{~m}$ plan genişliğinde, $\quad 2 \mathrm{~m} \quad$ yüksekliğinde laboratuvar ortamı için tasarlanmış üç boyutlu alüminyum bir çerçevedir. Yapının tasarımında mevcut ekipman ile ölçüm yapılabilmesine olanak veren sünek bir sistem olușturulması amaçlanmıştır. Yapıda her 0.5 m'de bir 2 $\mathrm{mm}$ kalınlığında galvaniz saç ile rijit katlar olușturulmuștur. Düşey taşıyıcılar $2 \mathrm{~cm}$ genişliğine ve $0.1 \mathrm{~cm}$ et kalınlığına sahip köșebent profillerden oluşmaktadır. Yapının rijitliği ve kütlesi sonradan eklenebilen çapraz elemanlar ve ek ağırlıklarla değistirebilmektedir. Çalışmada, piyasada ortalama bir fiyata sahip olan CANON EOS 650D marka bir kamera ve EF-S $18-55 \mathrm{~mm}$ lens kullanılmıștır. Kameranın resim örnekleme hızı ve çözünürlüğü sırasıyla 50 fps ve $720 \times 1280$ piksel'dir. Bu durumunda Nyquist-Shannon örnekleme teoremine göre $25 \mathrm{~Hz}$ 'in altındaki frekansların sağlıklı bir şekilde ölçülebileceği açıktır [22]. Deneysel yer değiştirmelerin elde edilmesinde test yapısının üçüncü katından ölçüm 
yapabilecek şekilde yatay olarak monte edilen bir adet LVDT kullanılmıștır. Yer değiştirme verileri, örnekleme hızı $30 \mathrm{~Hz}$ olan bir veri toplama cihazı ile kaydedilmiştir. Yapıya ait titreşim ivmelerinin ölçümü için dört adet tek eksenli Sensebox 702X serisi ivmeölçer her yapı katına sabitlenmiștir. $\mathrm{Bu}$ ivmeölçerlerin hassaslıkları 2400 ve
$6000 \mathrm{mV} / \mathrm{g}$ arasında değişmektedir. Mevcut şartlardaki deney düzeneği için oldukça yeterli hassaslık sunmaktadır. Verilerin toplanması 16 kanallı, 24 Bit ADC çözünürlüğe sahip Testbox2010 ile gerçekleştirilmiştir. Veriler $100 \mathrm{~Hz}$ örnekleme hızı ile kaydedilmiștir. Model yapı ve test düzeneği Şekil (5)'de verilmektedir.
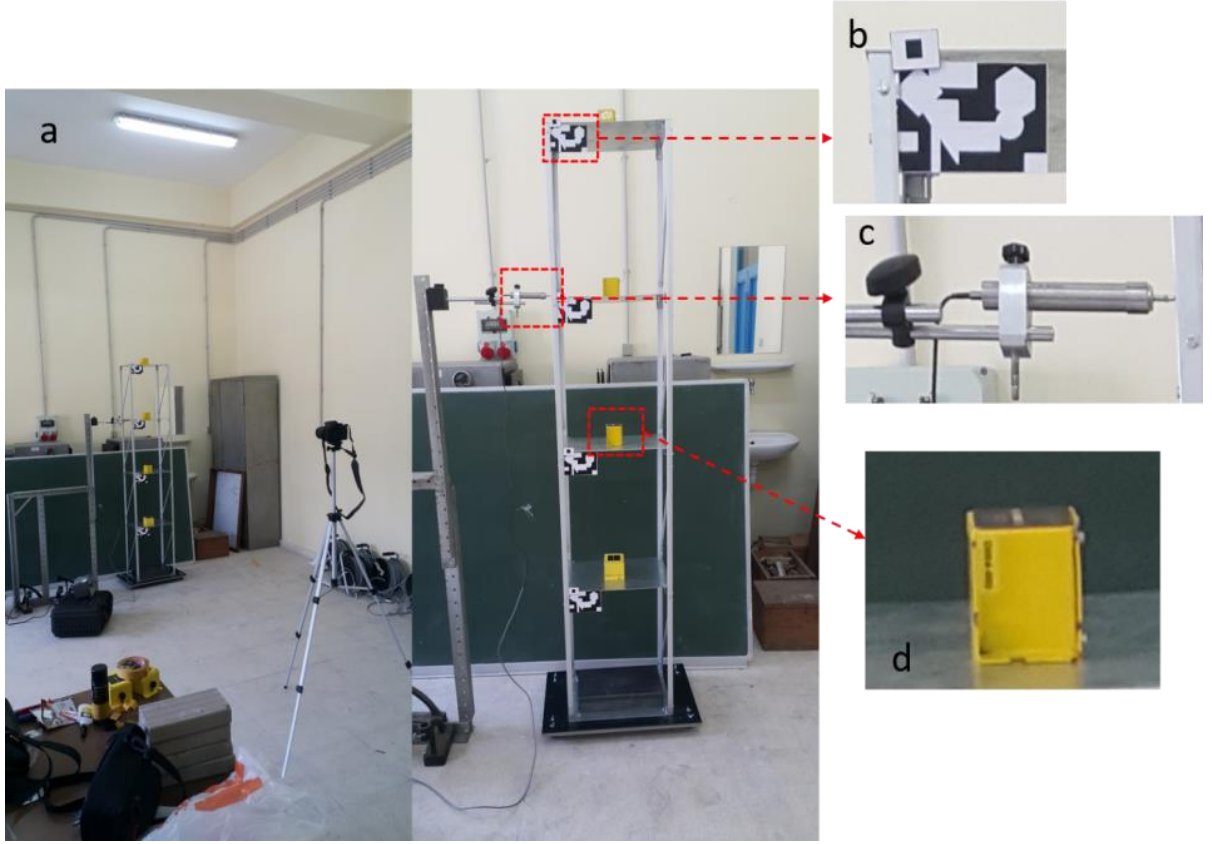

Şekil 5. a) Model yapı ve test düzeneği b) Yapay hedefler c) LVDT d) İvmeölçer

\section{Algoritmaların Karşılaştırılmalı Değerlendirilmesi}

\subsection{Yer değiștirmelerin sonuçları ile karşılaştırılması}

Bu bölümde görüntü işleme algoritmaları ile elde edilen yer değiştirmeler, yer değiştirmelerin ölçülmesinde kullanılan LVDT ile elde edilen sonuçlar ile karşılaştırılmıştır. Görsel akış yöntemiyle hız cinsinden büyüklükler elde edildiğinden bu bölümde karşılaştırmaya dahil edilmemiştir. Tüm yöntemlere ait algoritmaların kodları MATLAB teknik programlama dilinde geliştirilmiştir. Karşılaştırmalar kameranın yapıya olan iki farklı mesafesi için yapılmıștır. Fakat burada kameranın hedefe olan mesafesinden ziyade $\mathrm{mm} /$ piksel cinsinden $c$ katsayısı önem arz etmektedir. Çünkü yer değiştirmelerin ölçülmesindeki kesinlik $\mathrm{mm}$ başına düşen piksel sayısına bağlıdır. Kameranin hedefe olan mesafesi fazla iken düşük $c$ katsayısı için daha iyi lensler kullanılabilir. Bundan dolayı sonuçlar uzaklık yerine $c=0.4792$ ve $c=3.0935 \quad$ (mm/piksel) için karşılaştırılmıştır. Titreşim yapı katlarına çekiç yardımıyla uygulanan rastgele darbe yükleri ile elde edilmiştir. Şablon eşleştirme yöntemiyle elde edilen yapı titreşimine ait yer değiştirmeler, LVDT sonuçları ile $c=0.4792$ için Şekil (6)'de karşılaştırılmalı olarak verilmektedir. 
a

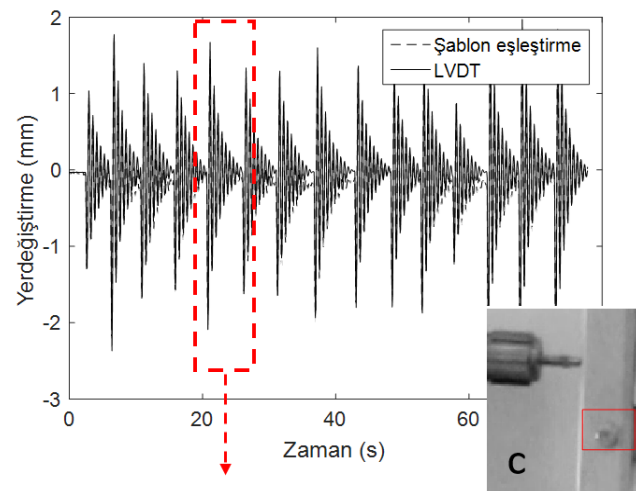

b
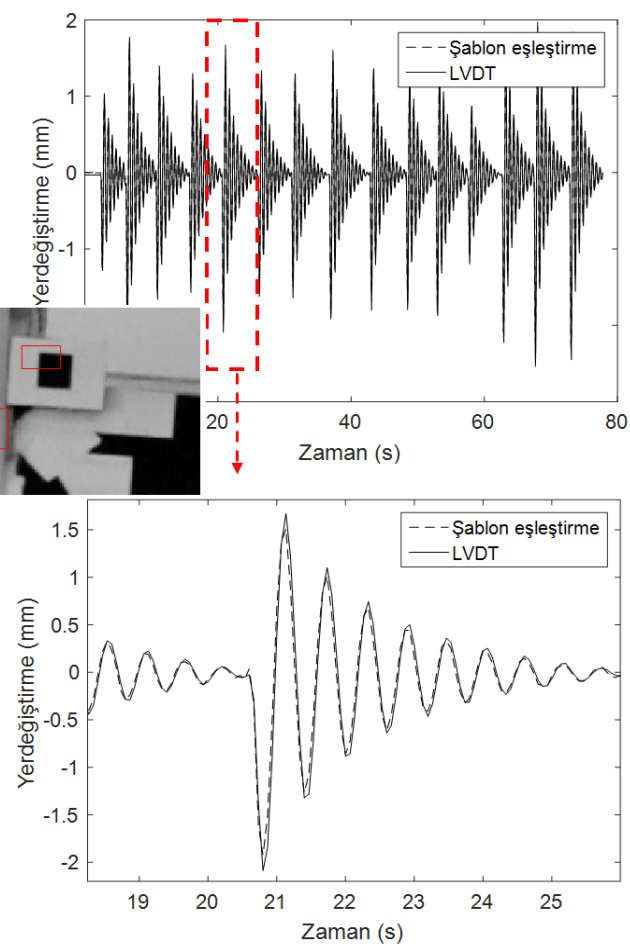

Şekil 6. Şablon eșleștirme ve LVDT sonuçlarının c= 0.4792 için karşılaştırılması a) doğal hedef takibi ile elde edilen yer değiştirmeler b) yapay hedef takibi ile elde edilen yer değiştirmeler c) Yapay ve doğal hedefler

Şekil 6'de verilen yer değiștirme-zaman grafiklerinden de anlaşlacağı üzere şablon eşleştirme yöntemiyle hem yapay hem de doğal hedef takibiyle elde edilen sonuçlar LVDT sonuçlarıyla yeterince iyi bir șekilde eșleșmektedir. Beklendiği üzere doğal hedef (bağlantı vidası) takibiyle elde edilen sonuçlar da biraz farklılık görülmektedir. Bu durum LVDT ile ölçüm alınan nokta ile hedef nokta konumundaki küçük farktan kaynaklanmaktadır. Şekil (7) 'da $c=$
0.4792 için KLT algoritması ile elde edilen sonuçlar karşılaştırılmalı olarak verilmiştir. Görüldügü üzere yapay hedef üzerinde seçilen bir noktanın takibi ile KLT algoritması sonuçları tatmin edici olsa dahi doğal hedef takibi ile elde edilen sonuçlar da sapmalar görülmektedir. Bunun nedeni titreşim süresince aynı noktanın takibinin yapılamamasıdır. Algoritma kimi zaman esas noktanın hemen yakınındaki başka bir belirteç noktayı takip edebilmektedir. 
a
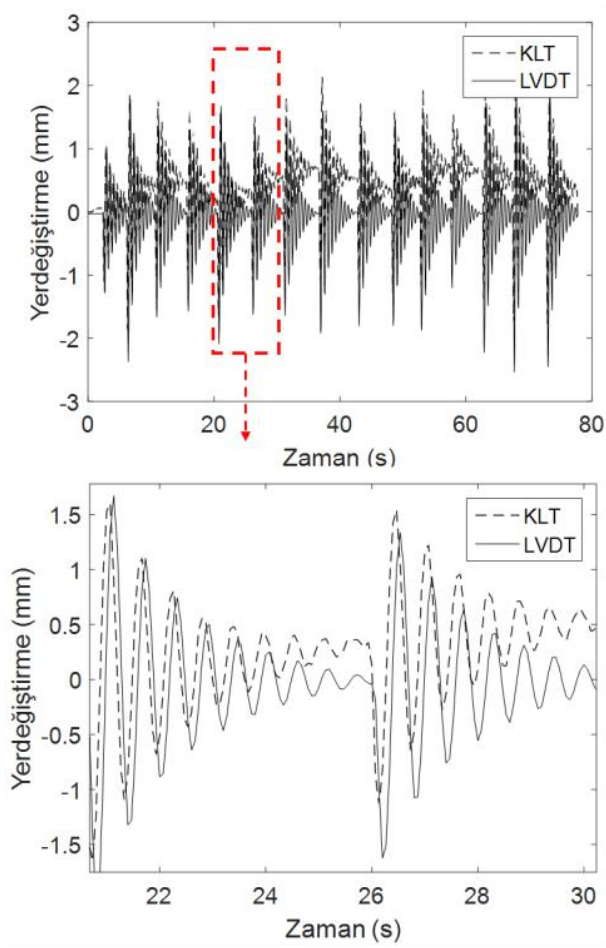

b
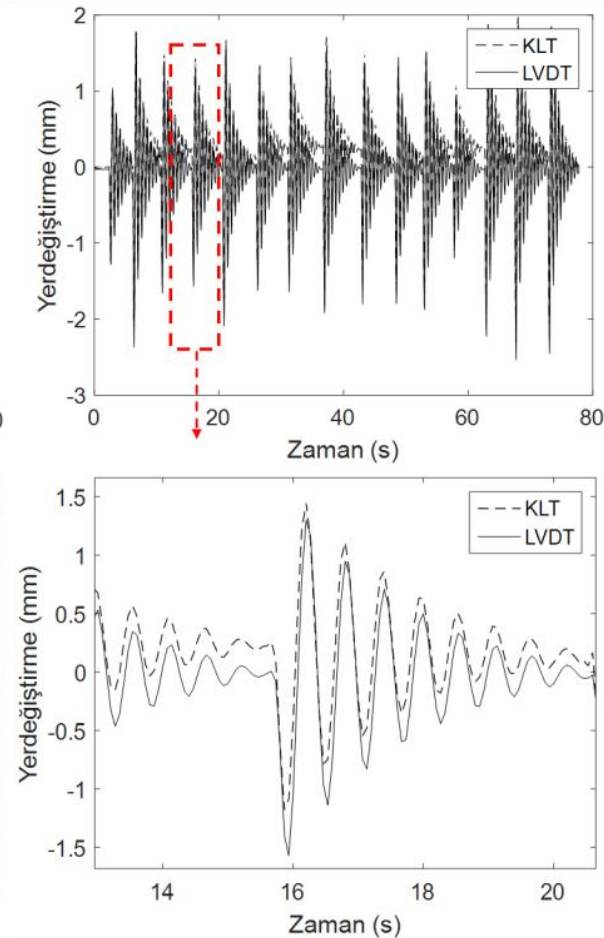

Şekil 7. KLT ve LVDT sonuçlarının c= 0.4792 için karşılaştırılması a) doğal hedef takibi ile elde edilen yer değiștirmeler b) yapay hedef takibi ile elde edilen yer değiștirmeler

Şekil (8)'de c=3.0935 için LVDT ve şablon eşleştirme yöntemi ile elde edilen yer değiştirmelerin karşılaștırılması verilmiştir. Yer değiştirmeler yapay hedef takibi ile elde edilmiştir. Şekil (8a)'da görüldüğü üzere LVDT sonuçları ile Şablon eşleştirmeden elde edilen sonuçlar arasında hafif bir sapma vardır. $\mathrm{Bu}$ durum, düşük piksel yoğunluğu nedeniyle asıl şablonun kesin bir şekilde takip edilememesinden kaynaklanmaktadır. $\mathrm{Bu}$ sapmadaki doğrusal eğilimin kaldırılması ile LVDT sonuçlarıyla daha iyi örtüşen bir grafik elde etmek mümkündür (Şekil 8b). Şekil (9)'da gösterilen KLT algoritması ile elde edilen sonuçlar da şablon eşleștirme ile elde edilen sonuçlara benzerlik göstermektedir. KLT algoritmasıyla elde edilen sonuçlarda sıfır ekseninden sapmanın daha az olduğu görülmektedir. Burada belirtilmesi gereken önemli bir husus ise KLT algoritmasının şablon eşleştirme yöntemine göre altpiksel yoğunluğu ve şablon büyüklüğüne bağlı olarak 3-5 kat hızlı olmasıdır. Piksel yoğunluğunun yeterli olduğu durumlarda (burada c=0.4792) yöntemlerin hızları arasında ciddi bir fark yoktur. Fakat piksel yoğunluğu azaldıkça (kameranın hedefe mesafesi arttıkça) şablon eşleştirme yöntemi için altpiksel uygulaması nedeniyle bu fark artmaktadır. Hesaplama zamanları; şablon eşleștirme, KLT ve görsel akıș algoritmaları için sırasıyla 276, 172 ve 177 saniye olarak hesaplanmıștır. Fakat şablon eşleştirme yönteminde altpiksel yöntemi ile piksel yoğunluğu 5 kat arttırılırsa hesaplama zamanı 620 saniyeye çıkmaktadır. Diğer iki yöntemde altpiksel uygulamasının sonuçlara etkisi yoktur. Hesaplamalar, Intel Corei75500U CPU@2.40GHz işlemcili 8 GB RAM kapasiteli dizüstü bilgisayarda yapılmıştır. 


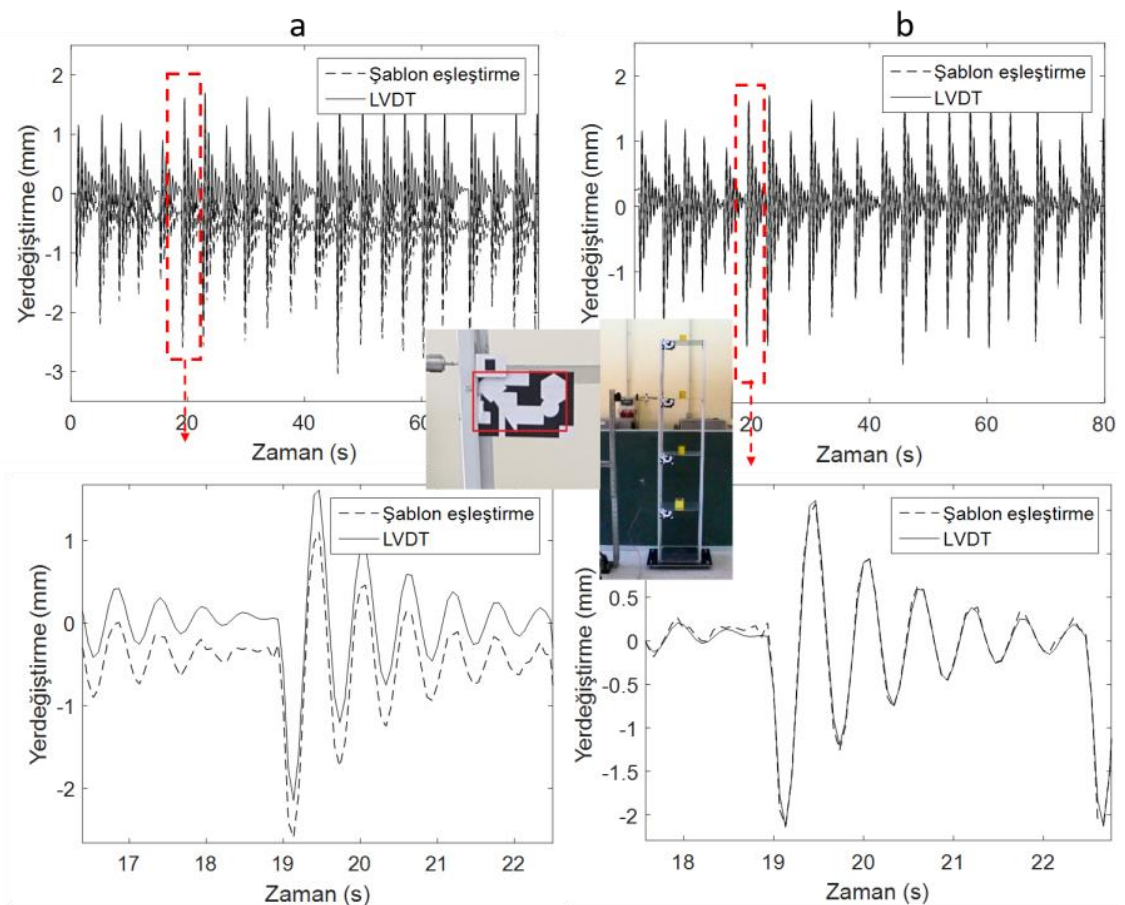

Şekil 8. Şablon eșleștirme ve LVDT sonuçlarının c= 3.0935 için karşılaștırılması a) Sıfır eksininden sapma eğilimi düzeltilmemiș durum b) Sıfır eksininden sapma eğilimi düzeltilmiș durum
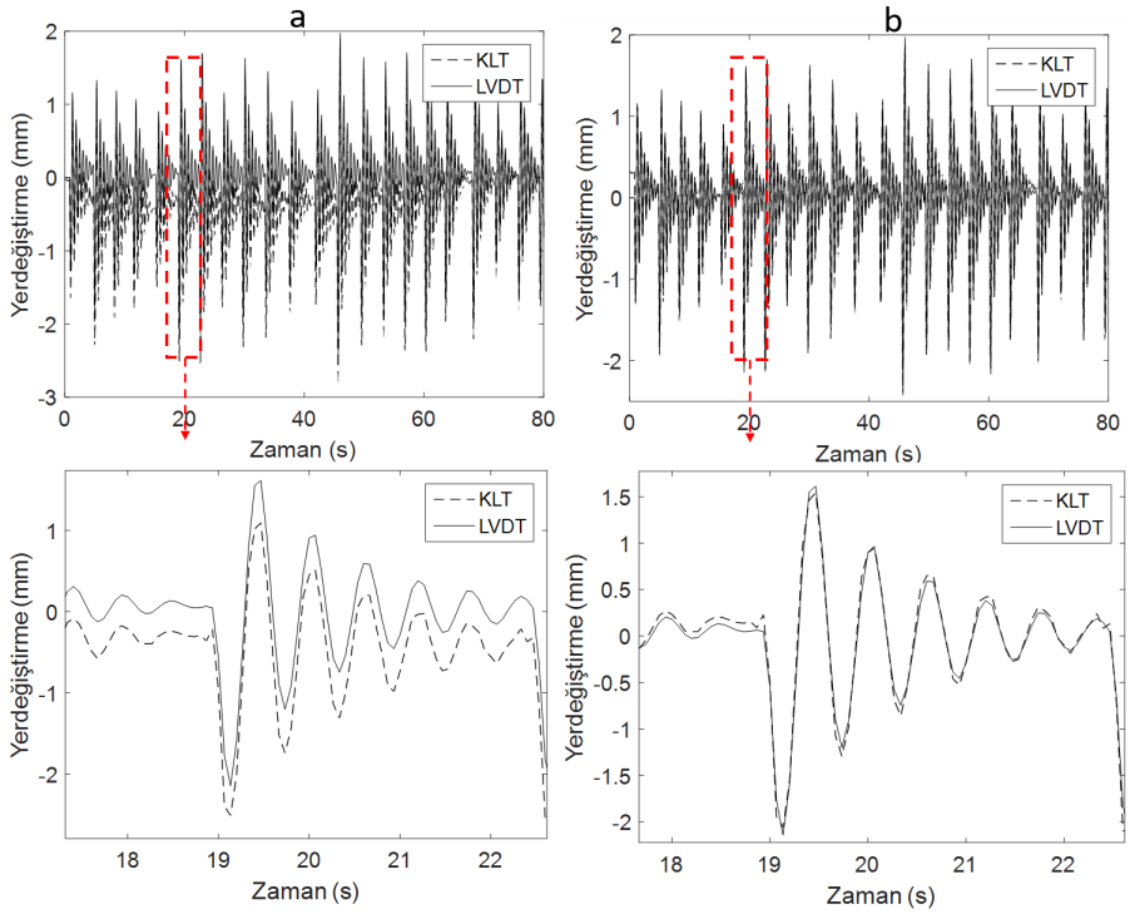

Șekil 9. KLT ve LVDT sonuçlarının c= 3.0935 için karșılaștırılması a) Sıfır eksininden sapma eğilimi düzeltilmemiș durum b) Sıfır eksininden sapma eğilimi düzeltilmiș durum 
4.2. Yöntemlerin frekans alanında karşılaştırılması ve modal tanılama $\mathrm{Bu}$ çalışma kapsamında ele alınan görüntü işleme algoritmaları, ivmeölçerler ile alınan kayıtlar ile frekans alanında karşılaştırılmıştır. Ayrıca karşılaştırmada titreşimin kaynağı açısından iki farklı durum ele alınmıștır. Birinci durumda titreşimin kaynağ katlara uygulanan başlangıç yer değiştirmeleri iken ikinci durumda rastgele darbe yükleridir. Başlangıç yer değiştirmeleri için katlara el yardımı ile $0.4-0.7 \mathrm{~cm}$ civarında yer değiștirme meydana getirecek itme uygulanmıș, darbe yükü için ise çekiç yardımıyla katlara kuvvet uygulanmıştır. Şekil (10)'da her iki durum için ivmeölçerler ve KLT algoritması ile elde edilen ivme ve yer değiştirmeler verilmektedir. Her iki durum için zaman alanında sunulan grafikler sayısal görüntü işleme yöntemleri için benzerlik göstermektedir. İvmeölçerler ile elde edilen ölçümlerde ise yüksek frekansların katkısı görülebilmektedir. Frekans alanındaki analizlerde bu durum daha açık bir şekilde görülmektedir. Şablon eşleştirme yöntemi, sonuçları KLT ile benzerlik gösterdiğinden burada verilmemiştir. 

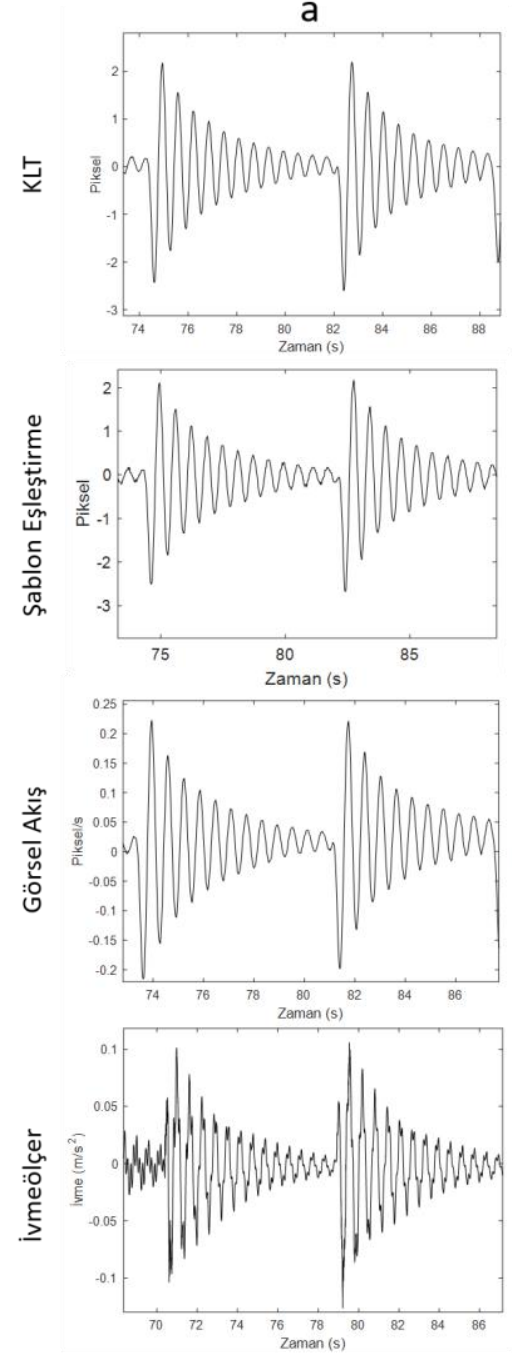

b
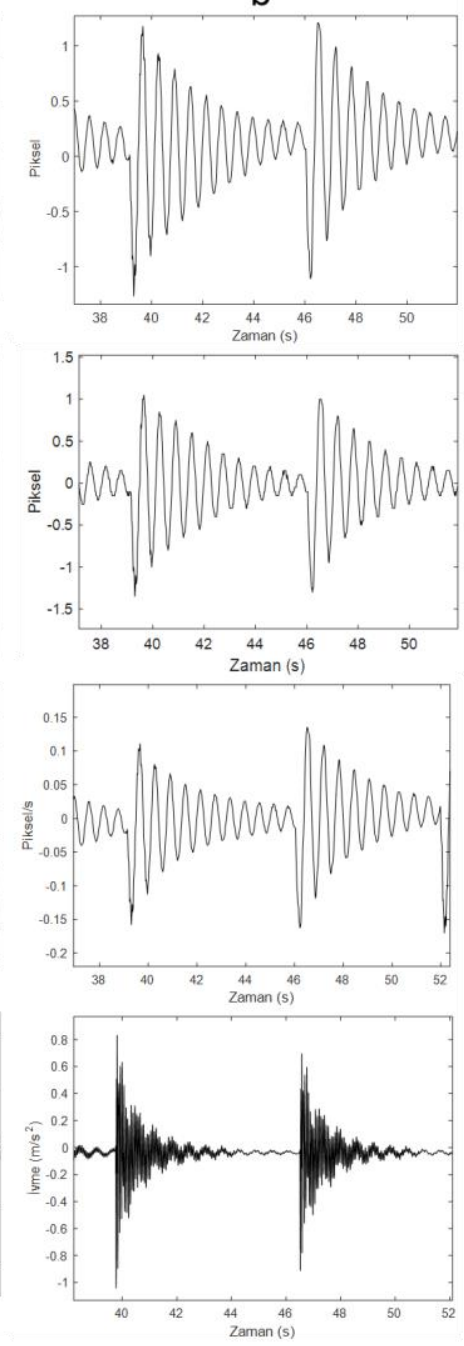

Şekil 10. KLT ,Şablon eșleştirme, Görsel Akış yöntemleri ve ivmeölçerler ile elde edilen ölçümler a) başlangıç yer değiştirmeleri (I.durum) ile b) darbe yüklemesi (II.durum) ile elde edilen büyüklükler

Sekil (11) 'da Frekans Alanı Ayrıklaştırma yöntemi kapsamında tekil değer ayrıklaştırması ile elde edilen tekil değer grafikleri KLT ve görsel akış yöntemleri ile ivme kayıtları için verilmektedir. KLT ve görsel akış yöntemleri ile elde edilen tekil değer grafikleri hemen hemen aynıdır. Burada dikkat çeken nokta ise titreşimin kaynağının başlangıç yer değiştirmesi veya darbe yüklemesi olması durumundaki farktır. Birinci durumda görsel akış yöntemleri ile üçüncü doğal frekans elde edilememiştir. İkinci durumda ise her üç frekans da görüntü işleme ile tespit edilebilmiştir. Bu durum aslında beklenmedik değildir. Çünkü yüksek frekansların enerjisi düșüktür ve yer değiştirmelere katkısı daha azdır. Titreşim kaynağı olarak başlangıç yer değiştirmelerinin kullanılması durumunda yüksek mertebeden frekanslar daha az tahrik edilmekte iken darbe yükü durumunda bu frekanslar 
daha çok tahrik edilmektedir. Böylece enerjileri yükselmekte, davranışa katkıları artmakta ve tekil değer grafiğinde rezonans frekansı olarak görünür hale gelmektedir. Genel olarak yüksek mertebeden frekansların görüntü tabanlı yöntemler ile elde edilen yer değiștirmeler ile tespiti daha güç olmaktadır. Daha iyi sonuç elde etmek

a
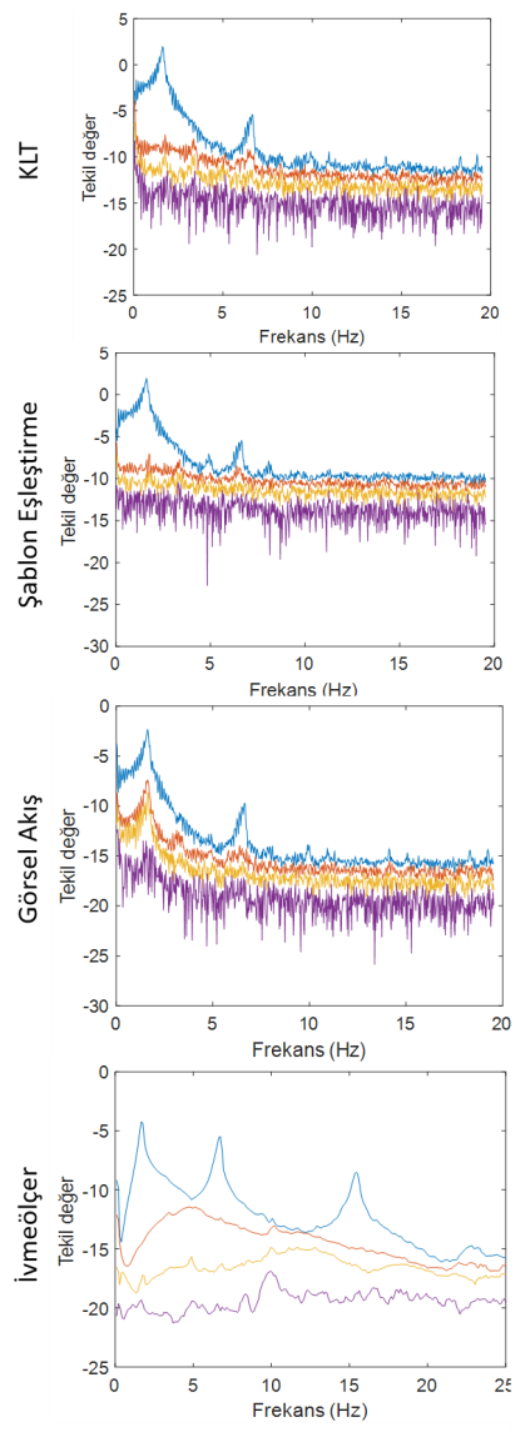

için piksel yoğunluğu ve frekans çözünürlüğü arttırılmalıdır. Beklendiği üzere ivmeölçerler ile elde edilen sonuçlar, her iki durum için de tatmin edicidir. Bu durum frekans içeriği zengin ivme kayıtlarının daha hassas bir şekilde elde edilmesinden ve yüksek örnekleme oranından kaynaklanmaktadır.

b
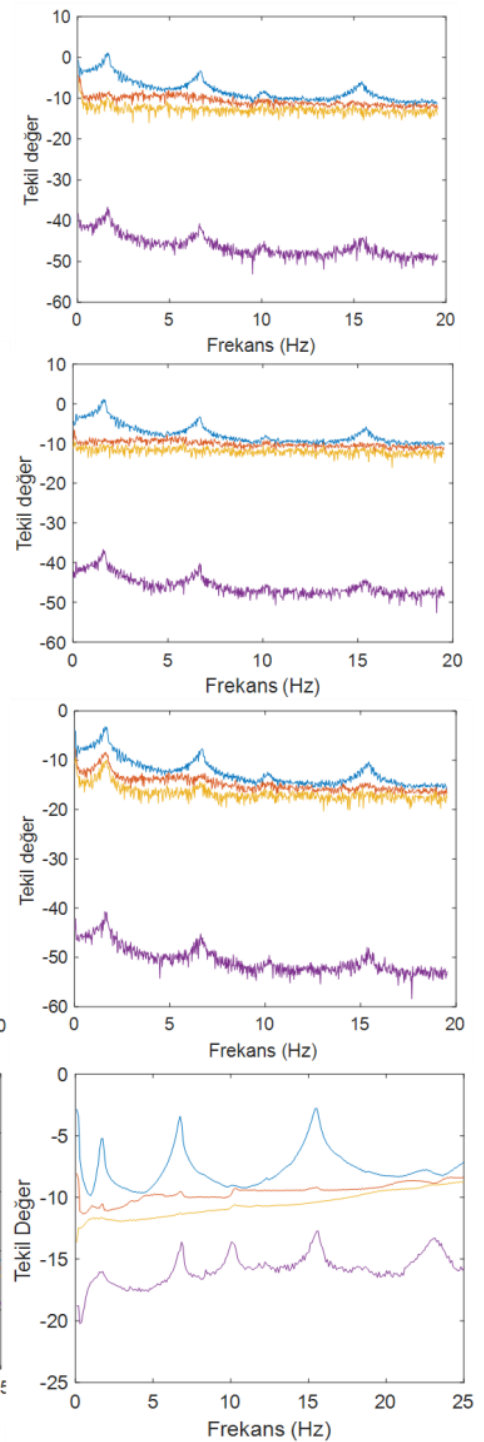

Şekil 11. KLT (1.satır), Şablon eşleştirme (2. satır) Görsel Akış (3.satır) yöntemleri ve ivmeölçerler (4. satır) ile elde edilen tekil değer grafikleri a) başlangıç yer değiștirmeleri ile b) darbe yüklemesi elde edilen grafikler 
Tayin edilen ilk üç doğal frekans ve sönüm oranları tüm yöntemler için Tablo (1)'de sunulmuștur. Görüldüğü üzere görüntü tabanlı yöntemler ve alışılagelmiş ivmeölçerler ile elde edilen sonuçlar birbirine oldukça yakındır. Görüntü işleme algoritmalarıyla elde edilen ilk üç doğal frekans için ivmeölçerlere göre hesaplanan ortalama hata oranı sirasiyla \%5.3, \%0.7 ve $\% 0.4$ 'tür. Ayrıca Şekil (12)'de verilen ilk üç mod şekli de tüm yöntemler için benzerdir. Anlaşllacağı üzere görüntü işleme tabanlı yöntemler ile deneysel modal parametrelerin yeteri yakınsaklıkta tayin edilmesi mümkün olmaktadır. Bu yöntemler tarafından sağlanan en büyük avantaj uygulamanın basitliğidir. Yaygın veri toplama yöntemlerindeki sensör yerleştirme, kablolama gibi zaman alıcı ve kimi zaman zorluklar içeren uygulamaların aksine bu yöntemlerde uygulamanın yapıldığı ortamda gerekli olan sadece kameradır. $\mathrm{Bu}$ noktada önemli olan uygulamaya bağlı olarak kameranın örnekleme hızı ve piksel yoğunluğu gibi faktörlerdir. Siradan inșaat mühendisliği uygulamalarında temel frekanslar genelde $20 \mathrm{~Hz}$ 'in altında olduğundan sıradan kameralar çoğu kez iyi sonuç verecektir. Ayrıca ani ışık değişimi gibi çevresel faktörlerin de sonuçlara etkisi olacaktır. $\mathrm{Bu}$ gibi durumlarda izlenen belirteç noktalarının veya şablonun bir sonraki video karesinde hatalı tespiti söz konusu olabilir. $\mathrm{Bu}$ da elde edilen yer değiştirmelerin hatalı olmasına neden olmaktadır.

Tablo 1 Çeşitli yöntemler ile elde edilen doğal frekans ve sönüm oranları (doğal frekansların birimi Hz'dir. Sönüm oranları parantez içinde verilmektedir.)

\begin{tabular}{|c|c|c|c|c|c|c|}
\hline \multirow{2}{*}{ Yöntem/Frekans } & \multicolumn{2}{|c|}{1} & \multicolumn{2}{|c|}{2} & \multicolumn{2}{c|}{3} \\
\cline { 2 - 7 } & I.durum & II.durum & I.durum & II.durum & I.durum & II.durum \\
\hline KLT & 1.61 & $1.63(4.7 \%)$ & 6.64 & $6.69(1.1 \%)$ & - & $15.43(4.48 \%)$ \\
Şablon Eşl. & 1.605 & $1.63(4.6 \%)$ & 6.63 & $6.71(1.2 \%)$ & - & $15.46(5.05 \%)$ \\
Görsel akış & 1.61 & $1.65(4.7 \%)$ & 6.64 & $6.69(1.2 \%)$ & - & $15.43(5.3 \%)$ \\
İvmeölçer & 1.71 & $1.71(4.1 \%)$ & 6.68 & $6.75(1.7 \%)$ & 15.49 & $15.49(5.5 \%)$ \\
\hline
\end{tabular}
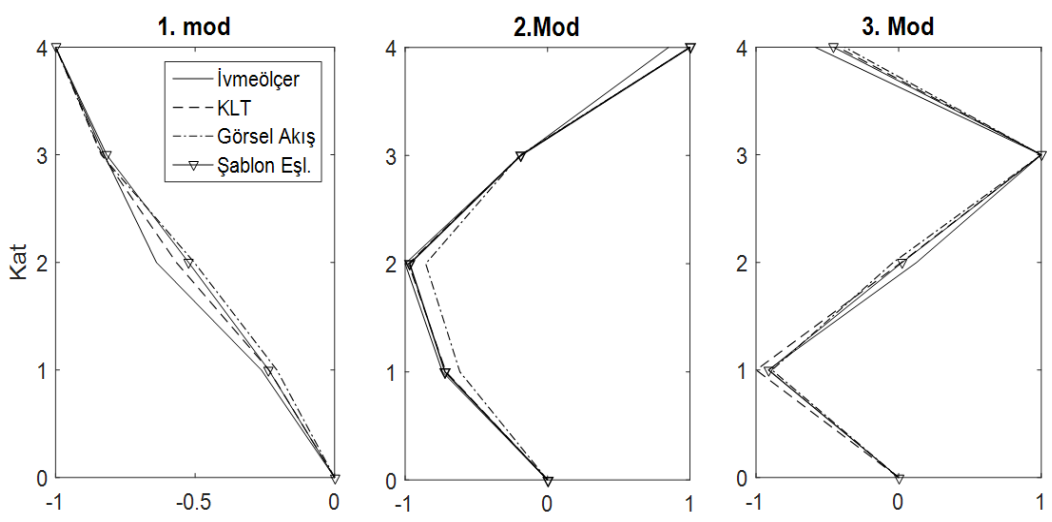

Şekil 12. Deneysel mod şekilleri (II. Durum için elde edilmiştir.)

\section{Tartışma ve Sonuç}

$\mathrm{Bu}$ çalışmada inşaat mühendisliği yapılarında titreșimin hiz ve yer değiștirme büyüklüklerinin ölçümünde sıkça kullanılan sayısal görüntü işleme teknikleri incelenmiştir. Bir laboratuvar test yapısı üzerinde yapay ve doğal hedeflerin takibi ile farklı mesafelerden ölçümler yapılmıș ve yöntemlerin performansları incelenmiștir. İlk olarak 
görüntü işleme yöntemlerinden elde edilen yer değiștirmeler, LVDT yardımıyla ölçülen yer değiștirmeler ile karşılaştırılmıștır. Ayrıca yöntemlerin performanslarını frekans alanında incelemek amacıyla görüntü işleme ile elde edilen deneysel modal parametreler alışılagelmiş ivmeölçerler ile alınan kayıtlar ile karşılaştırılmıştır.

Yakın mesafeden yapılan görüntü işleme ile elde edilen sonuçların LVDT sonuçları ile çok iyi eşleştiği görülmüştür. $\mathrm{Bu}$ durum birim alana düşen piksel sayısının oldukça fazla olmasının sonucudur. Uzak mesafeden yapılan ölçümlerde (piksel yoğunluğun 4-5 kat düşük olduğu durumda) sonuçların kalitesinde az da olsa bir düşüş görülmüştür. Bu durum titreşim süresince takip edilen hedeflerdeki veya belirteç noktalarındaki küçük sapmalardan kaynaklanmaktadır. Piksel yoğunluğu azaldıkça belirteç noktaların takibi güçleşmektedir. Fakat titreşimin genel eğilimi tüm yöntemler ile başarıyla bulunmuştur. Genel eğilimdeki sapmaların kaldırılmasıyla yer değiştirmelerdeki hata oranı \%0,5'in altında kalmıştır.

Görüntü işleme yöntemleri modal parametre tayininde de oldukça iyi sonuçlar vermiştir. $\mathrm{Bu}$ yöntemler ile elde edilen doğal frekans, mod şekli ve sönüm oranları gibi modal büyüklüklerin ivmeölçerler ile elde edilenlere oldukça yakın olduğu görülmüştür. İlk üç frekans için algoritmalardan elde edilen sonuçların ivmeölçerlere göre ortalama hata oranı darbe yükü altında sırasıyla $\% 5.3, \% 0.7$ ve $\% 0.4$ 'tür. Algoritmalardan elde edilen frekansların birbirlerine göre göreceli farkları ise \%0.3'ü geçmemektedir. Bunun yanında ivmeölçerler ile elde edilen sonuçlara kıyasla görüntü tabanlı yöntemler ile yüksek rezonans frekanslarının tespiti biraz daha güç olmaktadır. Yüksek frekansların yapı yer değiştirmelerine etkisi daha az olduğundan, tespitleri, bu frekansların ne kadar tahrik edildiğine bağlı olmaktır. $\mathrm{Bu}$ durumda daha yüksek frekans çözünürlüğü ve titreşiminin kaynağının ne olduğu önem kazanmaktadır.

Anlaşılacağı üzere geleneksel yöntemlere göre uygulama açısından çok daha pratik ve ucuz bir yöntem olan görüntü tabanlı hareket ölçme yöntemleri bu alanda önemli bir potansiyele sahiptir. $\mathrm{Bu}$ çalışmada incelenen üç yöntem de pratik uygulamalar için oldukça kullanışlıdır ve aralarında kesinlik açısından önemli bir fark görülmemiștir. Sadece şablon eşleştirme yönteminin hesaplama zamanı açısından KLT ve görsel akış yöntemlerine göre daha yavaş olduğu tespit edilmiştir. Ayrıca belirtilmelidir ki bu yöntemlerle elde edilen sonuçların kalitesi ve pratik uygulamalarda uzaktan mesafelerden ölçüm yapılması tamamen örnekleme hızı ve çözünürlüğü yüksek kameralar ve lenslere bağlıdır.

\section{Kaynakça}

[1] Mukhopadhyay, S.C., ed. 2011. New Developments in sensing technology for structural health monitoring, Lecture Notes in Electrical Engineering, Springer, Berlin.

[2] Brincker R, Andersen P, Jacobsen NJ., 2007. Automated frequency domain decomposition for operational modal analysis. Proceedings of IMAC-XXIV: A Conference and Exposition on Structural Dynamics. Society for Experimental Mechanics, Florida, USA.

[3] Van Overschee P., De Moor B. 1996. Subspace identification for linear systems: Theory - Implementation - Applications. Kluwer Academic 
Publishers, Dordrecht, The Netherlands

[4] Rainieri, C. ve Fabbrocino,G. 2014. Operational Modal Analysis of Civil Engineering Structures An Introduction and Guide for Applications, Springer, Berlin.

[5] Catbas, N.F., Correa,K.T ve Aktan,A.E. 2013. Structural Identification of Constructed Systems Approaches, Methods, and Technologies for Effective Practice of St-Id, American Society of Civil Engineers, ASCE,USA.

[6] Feng, M.Q., Fukuda, Y., Feng, D. and Mizuta, M. 2015 Nontarget Vision Sensor for Remote Measurement of Bridge Dynamic Response, Journal of Bridge Engineering, Cilt. 20(12), s. 1-11.

[7] Khuc, T. and Catbas, F.N. 2017. Completely contactless structural health monitoring of real-life structures using cameras and computer vision, Structural Control and Health Monitoring,Cilt. 24(1), s. e1852, DOI: $10.1002 /$ stc.1852

[8] Feng, D., Feng, M. Q., Ozer E. ve Fukuda Y. 2015. A Vision-Based Sensor for Noncontact Structural Displacement Measurement, Sensors, Cilt. 15, s. 16557-16575. doi:10.3390/s150716557

[9] Dworakowski Z., Kohut, P., Gallina, A., Holak K. ve Uhl, T. (2016) Vision-based algorithms for damage detection and localization in structural health monitoring,Structural Control and Health Monitoring, Cilt. 23, s. 3550. 10.1002/stc.1755

[10] Yoon, H., Elanwar, H., Choi, H., Fard,M.G., Spencer, B.F. 2016. Target-free approach for visionbased structural system identification using consumergrade cameras, Structural Control and Health Monitoring, Cilt. 23, s. 1405-1416. DOI: $10.1002 /$ stc. 1850
[11] Oh, B.K., Hwang, J.W., Kim,Y., Cho,T., Park, H.S. 2015. Visionbased system identification technique for building structures using a motion capture system, Journal of Sound and Vibration, Cilt. 356, s. 72-85. http://dx.doi.org/10.1016/j.jsv.20 15.07.011

[12] Feng, D., Feng, M.Q. 2017. Experimental validation of costeffective vision-based structural health monitoring, Mechanical Systems and Signal Processing, Cilt. 88, s. 199-211. http://dx.doi.org/10.1016/j.ymssp .2016.11.021

[13] Kohut, P., Holak,K., Uhl,T., Ortyl, L., Owerko,T., Kuras, P. And Kocierz, R. 2013. Monitoring of a civil structure's state based on noncontact measurements, Structural Health Monitoring Cilt. 12(5-6), s. 411-429. DOI: $10.1177 / 1475921713487397$

[14] Kim, S.W., Kim N.S. 2013. Dynamic characteristics of suspension bridge hanger cables using digital image processing, NDT\&E International, Cilt. 59, s. 25-33. http://dx.doi.org/10.1016/j.ndtein t.2013.05.002

[15] Ye, X.W., Dong, C. Z., Liu, T. 2016. A Review of Machine Vision-Based Structural Health Monitoring: Methodologies and Applications, Journal of Sensors, 7103039, 10 pages.http://dx.doi.org/10.1155/2 016/7103039

[16] Shi, J., Tomasi.C. 1994. Good features to track. IEEE Conference on Computer Vision and Pattern Recognition (CVPR'94), 593 - 600.

[17] Fredriksson, K., Ukkonen, E. 2001 Faster template matching without FFT. In: Proc. IEEE Intl. Conf. on Image Processing (ICIP). Volume 1, 678-681.

[18] Barron, J.L., Fleet, D.J., Beauchemin, S.S. 1994. 
Y.S. Erdoğan / Sayısal Görüntü İşleme ile Titreșim Yer Değiștirmelerinin Ölçümü ve Modal Parametre Tayini

Performance of optical flow techniques. International Journal of Computer Vision, Cilt. 12, s. 4377. DOI: $10.1007 / \mathrm{BF} 01420984$

[19] Ullah,F. Kaneko,S 2004. Using orientation codes for rotationinvariant template matching, Pattern Recognition Cilt.37, s. 201 - 209 doi:10.1016/S00313203(03)00184-5

[20] Ji,Y.F., Chang,C.C. 2008. Nontarget image-based technique for small cable vibration measurement, Journal of Bridge Engineering $\begin{array}{lllll}\text { Cilt.13, } & \text { s. } & 34 & - & 42\end{array}$ doi:10.1061/_ASCE_10840702_2008_ 13:1_34_

[21] http://avesis.yildiz.edu.tr/serhate/ dokumanlar

[22] Ewnis,D.J. 2000. Modal Testing: theory, practice and application, 2nd edition, Research Studies Press, England 